Pamiętnik Literacki 2021, 1, s. 57-74

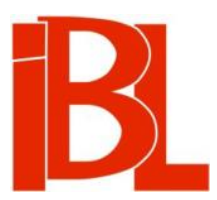

\title{
Sobowtórzenie Witkacego
}

\author{
Paweł Dybel
}


Pamiętnik Literacki CXII, 2021, z. 1, PL ISSN 0031-0514

DOI: $10.18318 / \mathrm{pl} .2021 .1 .4$

PAWEŁ DYBEL Uniwersytet Pedagogiczny, Kraków

SOBOWTÓRZENIE WITKACEGO

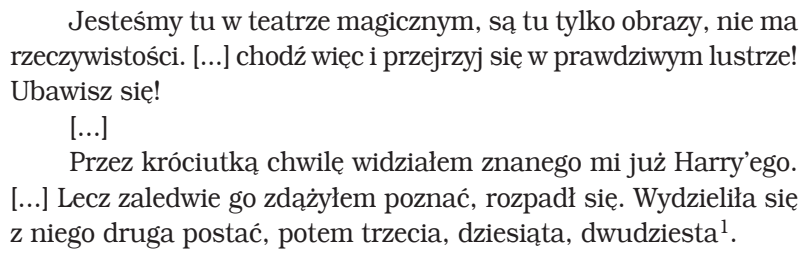

\section{W świecie odbić lustrzanych}

Kiedy patrzymy na fotografie Witkacego, uderza, że niemal na każdej z nich przybiera on jakąś minę czy pozę. Ot, choćby, gdy stojąc w wykroku z mocno przerażonym kotem w jednej ręce, w drugiej, wyciąnniętej przed siebie, trzyma pistolet zwrócony w stronę Tatr. Albo kiedy widzimy go w kąpieli $z$ wydętymi nienaturalnie policzkami, a za nim dwie roześmiane twarze kobiet. Lub też gdy zarzuciwszy poły marynarki na głowę zdaje się straszyć niczym wilkołak młodą damę. Jej uśmiech jednak sugeruje wymownie, że niewiele sobie $z$ tego robi. Takich zdjęć są dziesiątki.

Podmiot tych zdjęć nigdy nie jest tożsamy ze sobą. Zdystansowany ironicznie do siebie, jest nieuchwytny jak kameleon w swojej „wewnętrznej prawdzie”. Tak jakby obawa, że zdjęcie obnaży ową „prawdę”, rodziła spontanicznie gest obronny, chęć ukrycia siebie za maską miny, za którą nie ma już nic. Często przy tym maska ulega podwojeniu przechodząc od razu w kolejną, a ta w następną, itd. Widać to w cyklach fotografii, w których Witkacy parodiuje jakąś postać: wujka z Ameryki, strojącego głupawe miny urzędnika, człowieka-upiora... Kiedy patrzymy na te serie zdjęć, pojawiająca się w nich postać wydaje się nieuchwytna w tym, co o niej stanowi. Nie ma w niej nic stałego, dającego się uznać za jakiś jej trwały tożsamościowy wyróżnik. Nic tylko ciągłe prześmiewcze odsyłanie poza siebie w nieskończonym ciągu póz/min, w którym każda przechodzi od razu w kolejną, odsyłając do następnych. Cała domniemana tajemnica i „głębia” osoby na fotografii zdaje się tu być na powierzchni, jej domniemane „wnętrze” przeszło na zewnątrz, wyobcowało się wobec siebie w jakimś pokracznym grymasie, w którym nie został po nim najmniejszy nawet ślad.

Tę podwajającą się w nieskończoność strukturę prześmiewczej, autoironicznej

1 H. He s s e, Wilk stepowy. Powieść. Przeł. J. Wittli n. Warszawa 1957, s. 200-201. 
relacji do siebie oddaje otwierający 622 upadki Bunga obraz barona Brummela, który traktuje życie realne i ludzi jako coś wstrętnego i niezrozumiałego:

Żył w świecie, który można by porównać do olbrzymiego labiryntu zwierciadlanych komnat, w których najmniejsza zmiana układu odbita w dziwacznie pokrzywionych ścianach wracała w nieskończonych wariacjach do centrum tego układu, tworząc dopiero wtedy jego istotne bogactwo ${ }^{2}$.

Świat barona Brummela to świat podwajających się nieustannie odbić lustrzanych, które dając mocno zniekształcony obraz realnych rzeczy i ludzi są dla niego, wzięte jako całość, jedynym punktem odniesienia w myśleniu o rzeczywistości. Żyje on przeniesiony w swojej wyobraźni w ten świat, który w jego oczach zyskał status samowystarczalnego bytu. I jako taki pozostaje w jaskrawej opozycji w stosunku do realnego bytu na zewnątrz, który napawa Brummela obrzydzeniem i wstrętem. $Z$ tym samoistnym statusem świata, w jakim żyje bohater powieści Witkacego, koresponduje równie samoistna postać jego psychiki, która jest „izolowanym systemem, rządzonym jedynym prawem mnożenia się w nieskończoność jednego, niezmiennego w swojej istocie, obserwatora" 3 .

Tak samo zatem jak lustrzane odbicia komnat w świecie barona mnożą się w nieskończoność, multyplikacji ulega obserwujące ,ja” owego barona, który na nie patrzy, nie mogąc nigdy usadowić się na stałe w jednym $z$ tych odbić. Jego tożsamość znajduje się w ciagłym ruchu przekraczania siebie ku swym kolejnym postaciom. Wygląda to tak, jakby owo ,ja” obserwujące nie mogło nigdy zidentyfikować się na trwałe $\mathrm{z}$ jednym obrazem siebie, ale ten nieustannie się podwaja, przynosząc nowe oblicza siebie. Nie sposób nie odwołać się do analogii z przytoczoną w motcie sytuacją z powieści Hermana Hessego, w której jej bohater Harry spoglądając w lustro, rozpada się na wiele swoich odbić:

Wreszcie całe olbrzymie zwierciadło zaroiło się od samych Harrych czy też od odłamków Harry’ego, od niezliczonych Harrych, $\mathrm{z}$ których każdego $\mathrm{z}$ osobna przez mgnienie oka widziałem i rozpoznawałem. [...] byli w moim wieku, jedni starsi, inni prastarzy, a inni znów młodzi, młodzieńcy, chłopcy, uczniowie, smarkacze, dzieci. [...] poważni i weseli, godni i komiczni, dobrze ubrani i obszarpani, a nawet całkiem nadzy, łysi i długowłosi, a wszyscy byli mną ${ }^{4}$.

„Ja” Harry’ego i ,ja” barona Brummela przypominają ślizgający się pod ciągiem znaczących „pęknięty” podmiot Lacanowski, który istnieje tylko o tyle, o ile jedno znaczace przedstawia go innemu znaczacemu ${ }^{5}$. I wraz ze zmianą owych znaczących/min obrasta w nowe tożsamościowe formy, które wciąż przechodzą w następne. Taki podmiot nie ma żadnej „esencji”, jakiegoś stałego tożsamościowego rysu, z którym mógłby się raz na zawsze zidentyfikować, ale jest funkcją nieustannie zmieniającego się odniesienia kolejnych znaczących/odbić do siebie.

Jest on jako taki bez wnętrza, staje się w ciagłym ruchu przemian, nie dając się do żadnego ze swoich znaczących przytwierdzić na zawsze. Jego dewizę stano-

2 S. I. W itki ew i z, 622 upadki Bunga, czyli Demoniczna kobieta. Wstęp, oprac. A. Micińs ka. Warszawa 1972, s. 52.

Ibidem.

Hes s e, op. cit., s. 201.

J. La can (Écrits. Paris 1966, s. 819) formułuje tę myśl w zdaniu: „Znaczącym jest to, co przedstawia podmiot innemu znaczacemu”. 
wi ustawiczna ucieczka przed sobą w coraz to nowe miny/pozy, permanentne przepoczwarzanie się bez stabilnego punktu zaczepienia. Wszystko jest w nim nałożoną na twarz chwilowo maską, którą szybko musi porzucić na rzecz kolejnej, tę na rzecz następnej, itd.

To przeniesienie się podmiotu w obręb świata lustrzanych odbić, które mnożą się w nieskończoność i którym towarzyszy równie nieskończona multyplikacja tego, kto je obserwuje, oddaje zarazem sposób, w jaki Witkacy już u progu swojego pisarstwa ujmuje relacje między sztuką a rzeczywistością. Podobnie jak mnożące się w lustrze odbicia barona Brummela lustrzany świat sztuki tworzy zamknięty, samotłumaczący się system odbić, na który składają się odnoszące się do siebie w nieskończoność dzieła. Przekonanie to znajdzie potem swój wymowny wyraz w głoszonej przez Witkacego teorii Czystej Formy, ale tkwiące u jej podstaw założenia rozpoznajemy już w tej pierwszej powieści, którą zaczął on pisać w 1910 roku. Widać to wyraźnie w późniejszych dyskusjach, jakie Bungo toczy z księciem Nevermore i z panią Akne na temat sztuki i jej relacji do rzeczywistości.

W przeniesieniu się podmiotu w świat lustrzanych odbić, których relację do siebie określa logika multyplikacji, każde zaś kolejne odbicie jest deformacja poprzedniego, można widzieć rodzaj ucieczki tego podmiotu przed budzącym u niego obrzydzenie światem realnych ludzi i rzeczy. Zarazem jednak da się w tym dostrzec jego ucieczkę przed sobą samym, przed czymś, czego ów podmiot się lęka, a niewykluczone, że nawet czuje do tego wstręt. Czym jest w takim razie owo „coś”? Czy chodzi tu o jakiś jego obraz siebie, którego za żadną cenę nie chce on pokazać innym? Choćby ten, który kazał mu spalić listy pisane do ojca?

Ale równie dobrze można by doszukiwać się innych motywów tej decyzji. Wydany w 1986 roku wspaniały album z reprodukcjami zdjęć zrobionych przez Witkacego i różnych fotografii z życia jego rodziny i jego samego ma wymowny tytuł: Przeciw Nicości. Przeciw Nicości, a więc przeciw bliżej nieokreślonemu „czemuś”, co wprawdzie nie istnieje i jako takie nie da się zdefiniować, a jednak okazuje się w swoim nieistnieniu trudne do zniesienia. Co jest w takim razie niepokojącego w owym Nic, tak że Witkacy szuka przed nim schronienia w różnych przyjmowanych przez siebie prześmiewczych pozach i maskach? Co każe mu wypowiadać osobliwe twierdzenia o „dziwności” istnienia i przenikającej cały byt „Tajemnicy”, której po stronie podmiotu odpowiada poczucie przeraźliwej samotności i absurdu wszystkiego?

\section{Autoportret wielokrotny i cztery sobowtóry Witkacego}

Podobne pytania narzuca nam bodaj najbardziej znana i zagadkowa zarazem fotografia Witkacego z okresu jego służby w wojsku carskim w Petersburgu, zatytułowana Autoportret wielokrotny $w$ lustrach. Pochodzi ona z 1916 roku i była zrobiona w profesjonalnej pracowni fotograficznej. Witkacy, ubrany w mundur oficera Pawłowskiego Pułku, z przechyloną lekko na lewo żołnierską czapką i odwrócony do patrzacych tyłem, ukazany został na niej wraz z czterema swoimi odbiciami/sobowtórami na dwóch ustawionych wobec siebie pod pewnym kątem lustrach. Przy czym, rzecz znamienna, kat nachylenia luster nie był identyczny. Lustro po lewej stronie Witkacego jest bowiem bardziej nachylone do niego niż lustro po stronie prawej. Sprawia to, że nie tylko dwa jego odbicia/sobowtóry umieszczone en face, 


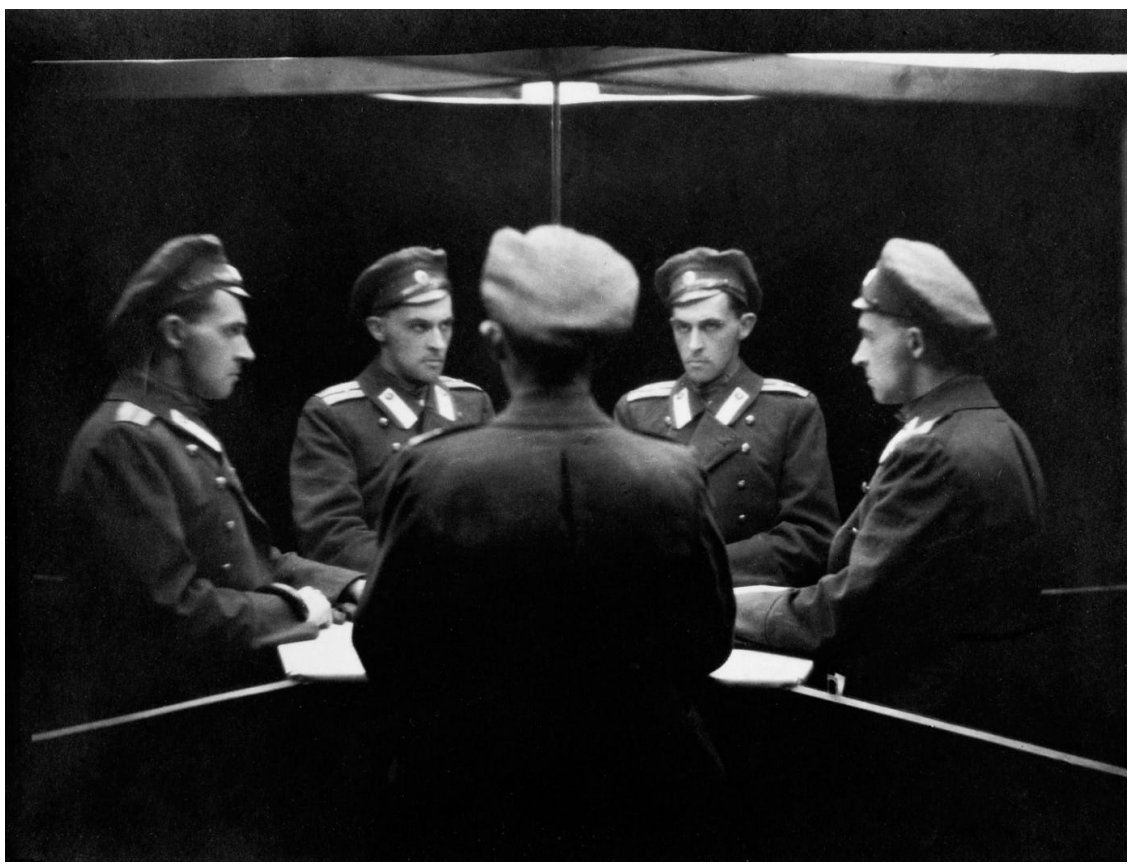

Stanisław Ignacy Witkiewicz, Autoportret wielokrotny $w$ lustrach

ale również i kolejne sobowtóry, usytuowane całkiem $z$ boku, nie są symetryczne względem siebie. Ta asymetria nadaje fotografii niezwykłą dramaturgię, ponieważ spojrzenia wszystkich znajdujących się na niej odbić/sobowtórów pisarza pozostają wobec siebie w różnych relacjach.

Jest to ważny szczegół, gdyż odmienny kąt nachylenia obu luster decyduje o układzie pozycji czterech sobowtórów wobec siebie i wobec odwróconego do nas tyłem Witkacego. Stanowi to też o złożonej dramaturgii toczącej się między nimi gry spojrzeń. Jeśli więc przykładowo sobowtór pierwszy, usytuowany en face $z$ lekkim nachyleniem, po prawej stronie Witkacego, patrzy na niego wprost, to sobowtór drugi, znajdujacy się po jego lewej stronie, jako umieszczony wobec niego bardziej ukośnie kieruje spojrzenie na sobowtóra trzeciego, siedzącego bokiem po prawej stronie Witkacego. Również ukośną pozycję wobec pozostałych zajmuje sobowtór czwarty, także siedzacy bokiem, lecz po lewej stronie Witkacego. Patrzy on na sobowtóra trzeciego, nie będąc przez niego dostrzeżony. Co ciekawsze, nie widzą go też dwa pozostałe sobowtóry, jak i sam Witkacy.

Jeśli chodzi o dotychczasową literaturę, w której podejmowano próby interpretacji tego zdjęcia, na szczególną uwagę zasługuje esej Daniela Geroulda6 ${ }^{6}$ Krytyk skoncentrował się w nim jednak na czysto psychologicznej charakterystyce ukazanych na fotografii Witkacego postaci, w dość dowolny sposób wyczytując z wy-

6 D. G e rould, Witkacy i jego sobowtóry. Przeł. J. Ko s i c ka. „Pamiętnik Teatralny” 1985, nr 1/4: Stanisław Ignacy Witkiewicz 1885-1939, s. 133-136, 149, 151. 
glądu ich twarzy, układu ciała i rak cechy osobowości schizofrenicznej (rozszczepienie jaźni, autorepresyjność, lęk, drżenie rąk, itd.). Ja w mojej interpretacji tej fotografii chciałbym zwrócić uwagę na coś zupełnie innego. Interesuje mnie przede wszystkim struktura relacji zachodzącej między Witkacym a jego czterema sobowtórami oraz znaczenie, jakie można by przypisać odmiennemu usytuowaniu wobec niego każdego z owych sobowtórów.

\section{Asymetria lustrzanych odbić. Dwie sekwencje}

Grę spojrzeń Witkacego i jego czterech sobowtórów w Autoportrecie można podzielić na dwie sekwencje, przebiegające tu równolegle względem siebie: sekwencję tworzona przez Witkacego i patrzącego na niego wprost sobowtóra pierwszego oraz sekwencję budowana przez Witkacego kierującego wzrok na sobowtóra drugiego, który spogląda nie na niego, lecz na sobowtóra trzeciego, ten zaś z kolei odwzajemnia mu symetrycznie jego spojrzenie. Sekwencję tę kończy sobowtór czwarty, który obserwuje sobowtóra trzeciego, będąc sam przez niego niezauważony. Nie jest on również dostrzegany przez podmiot/Witkacego ani przez pozostałe sobowtóry. Widzą go wyłącznie osoby oglądające fotografię, tylko one mają pełny obraz gry spojrzeń, jaka odbywa się między podmiotem/Witkacym a jego zwierciadlanymi sobowtórami.

Obie sekwencje spojrzeń łączy postać podmiotu/Witkacego. W pierwszej sekwencji jest ona obiektem spojrzenia sobowtóra pierwszego, w drugiej sekwencji patrzy na sobowtóra drugiego, który jej nie dostrzega. Natomiast gra spojrzeń między sobowtórem drugim, trzecim i czwartym toczy się już samorzutnie bez udziału podmiotu/Witkacego ${ }^{7}$.

To zdjęcie możemy uznać za arcydzieło sztuki fotograficznej, przedstawiające konfrontacje jednostki ze swoimi czterema odbiciami/sobowtórami w dwóch nachylonych do siebie pod pewnym kątem lustrach. Ten pomysł miał zresztą również swoje inne realizacje w owym czasie ${ }^{8}$, a o jego oryginalności stanowi fakt, że dzięki odpowiednio nachylonym dwóm lustrom uzyskuje się efekt roz-po-czwórzenia postaci realnego podmiotu na fotografii, tak iż między nim a jego lustrzanymi odbiciami/sobowtórami tworzy się złożona siatka przecinających się spojrzeń. Można

7 Wydaje się, że właśnie podobnnie przedstawiała się struktura „węzłowisk”, które oplatały rozdzieraną rozmaitymi konfliktami duszę Witkacego. Przybierając wobec innych różnego rodzaju maski/pozy wchodził on w ten sposób w rolę obiektu-sobowtóra samego siebie, co pozwalało mu odpowiednio manipulować innymi: rozgrywać wobec nich swoją własną grę (np. kiedy pisał do Heleny Czerwijowskiej, że jest ona jedyną kobietą, którą mógłby kochać). Równocześnie był wystawiony jako obiekt na przenikliwie podejrzliwe spojrzenie innego sobowtóra, który występował wobec niego w roli patrzącego nań podmiotu i z którym musiał zacząć prowadzić innego rodzaju grę.

8 Pisze o tym S. Ok ołow i c z, autor wstępu do albumu zdjęć S. I. Wit ki e w i c za (Przeciw Nicości. Fotografie Stanisława Ignacego Witkiewicza. Red. E. F r a n c z a k, S. O k oł ow i c z. Kraków 1986, s. 27): „Lustra i sobowtórowe odbicia w nich znane były z dziewiętnastowiecznych powieści. Również na początku dwudziestego wieku wielu artystów używało luster w celu uzyskania podobnych efektów. Taką samą fotografię jak Witkacy zrobił sobie m.in. polski architekt Wacław Szpakowski w 1912 roku, Marcel Duchamp w 1917 roku i włoski futurysta Umberto Boccioni. Również w krótkometrażowym filmie The Play House (1921 r.) Buster Keaton kreuje scenę, w której jego postać odbija się w trzech lustrach jednocześnie. Opis odbicia w lustrach znajdujemy m.in. w powieści Hermana Hessego Wilk stepowy [...]". 
w tym widzieć rodzaj zabawy i wtedy fotografię odczytuje się w sposób dosłowny. Zgodnie $\mathrm{z}$ takim odczytaniem to tylko zwykła gra lustrzanych odbić, za która nic godnego uwagi się nie kryje.

Ale w Autoportrecie Witkacego da się też dostrzec znacznie więcej. Ot, choćby metaforę dysocjacyjnej struktury tożsamościowej podmiotu, rozbitej na kilka sobowtórów/wcieleń. Wszystko staje się wtedy w swej absurdalności zagadkowe i obce. Załóżmy, że te pięć osób, jedna po „tej” stronie lustra (podmiot/Witkacy), cztery pozostałe po „tamtej”, faktycznie siedzi przy jednym stole, patrząc na siebie pod różnym kątem. Nasuwa się wówczas pytanie: co oznacza siatka ich przecinających się spojrzeń? W jaki sposób zidentyfikować pozycję każdej z nich i to, jak jej spojrzenie odnosi się do spojrzeń innych?

W dodatku, jeśli weźmiemy pod uwage, że motyw sobowtóra pojawia się już we wczesnych listach Witkacego do Heleny Czerwijowskiej, jak też w 622 upadkach Bunga (i to wielokrotnie), Autoportret zyskuje szczególne znaczenie. O co w takim razie w nim chodzi? Jakie jest stojące za nim przesłanie?

\section{Spojrzenie wprost pierwszego sobowtóra}

Kluczowa postacią w Autoportrecie jest odwrócony tyłem do patrzacych na fotografię ,realny” Witkacy. O tym, jak wygląda jego twarz, możemy wnioskować jedynie na podstawie wyglądu czterech jej lustrzanych odbić/sobowtórów. Ona sama jest niczym Kantowska „rzecz w sobie” czy Freudowskie nieświadome, jako taka nam niedostępna. W dodatku każde $\mathrm{z}$ jej czterech odbić/sobowtórów prezentuje ją pod innym katem: dwa odbicia typu en face, ale w lekkim przechyleniu na prawą i lewą stronę, oraz dwa odbicia profilem $z$ dwóch stron.

Największą zagadką na fotografii jest dla patrzących na nią zatem sam „realny” Witkacy. Możemy o nim powiedzieć jedynie to, co ukazują nam na fotografii twarze jego czterech zwierciadlanych odbić/sobowtórów. Postrzega on przy tym bezpośrednio tylko dwa $z$ nich (sobowtór pierwszy i sobowtór drugi), dwa pozostałe zaś są dla niego $\mathrm{z}$ pozycji, jaką zajął, niewidoczne. W dodatku każdy $\mathrm{z}$ dwóch pierwszych sobowtórów, $z$ racji odmiennego kąta nachylenia wobec niego, pozostaje z nim w radykalnie innej relacji. Ale w równej mierze zagadkę stanowi dla siebie na fotografii sam Witkacy. Także i on dany jest na niej sobie jedynie poprzez swoje cztery odbicia/ sobowtóry.

Autoportret można uznać za wymyślną metaforę dysocjacyjnej struktury tożsamościowej Witkacego. Ukazany on jest jako podmiot, który spoglądając w ustawione naprzeciw niego dwa lustra, rozszczepił się na cztery swoje odbicia/sobowtóry, przy czym każdy $z$ nich pozostaje $z$ nim $w$ odmiennej relacji. To rozszczepienie będzie potem stałym rysem jego życia i twórczości, znajdując swoje wymowne poświadczenie w jego listach, dramatach i powieściach. Wiązać się będzie ono ściśle z tym, co później w Niemytych duszach nazwie pisarz „węzłowiskami”, określając w ten sposób Freudowskie pojęcie kompleksu.

Spójrzmy jeszcze raz na fotografię. Jak już pisałem, tworza ją dwie sekwencje spojrzeń, które łączy odwrócony do nas tyłem podmiot/Witkacy. Sekwencje te biorą swój początek w relacji, w jakiej „realny” podmiot/Witkacy na fotografii pozostaje ze swymi dwoma lustrzanymi sobowtórami siedzacymi naprzeciw niego. 
Pierwszą sekwencję otwiera sobowtór pierwszy siedzący na wprost podmiotu/ Witkacego, usytuowany po jego prawej stronie. Ten sobowtór utkwił w nim przenikliwe spojrzenie, $z$ wyraźnym odcieniem podejrzliwości. Ponieważ podmiot/Witkacy jest odwrócony do nas tyłem, nie wiemy, jak wygląda jego reakcja. Chociaż nie, wiemy; wszak ten patrzący na niego sobowtór to przecież zwierciadlany obraz jego samego.

Właśnie jednak dlatego konfrontacja ich spojrzeń jest tak intrygująca. Ten śmiertelnie poważny młody człowiek spoglądający na mnie podejrzliwie w lustrze, $z$ lekkim ironicznym uśmiechem na ustach, to przecież nikt inny jak ja sam. W jaki więc sposób mam się wobec niego/siebie zachować? Czy mam starać się wytrzymać jego spojrzenie i wpatrując się w niego równie nieustępliwie, zmusić go do opuszczenia oczu? Przecież „tamten” będzie patrzył na mnie dalej tak samo natarczywie jak ja na niego. I nigdy nie ustąpi. Tak jak nie ustąpił ten, którego twarz Narcyz zobaczył w lustrze wody.

Warto zauważyć, że motyw bezpośredniej konfrontacji z uporczywym spojrzeniem innego/sobowtóra, które rodzi przerażenie, pojawia się kilkakrotnie w 622 upadkach Bunga. Szczególnie wymowna pod tym względem scena ma miejsce w nocy w górach, kiedy Bungo, po tym jak mieszkająca $z$ nim w chacie Angelika idzie do swego pokoju, kończy rysowanie i leżąc na sofie ma „wrażenie, że ktoś stoi za nim”9. To wrażenie potęguje widok wiszących ubrań w mrocznym pokoju oraz znajdujących się w nim sprzętów, w tym niewielkiego zwierciadła:

odbijało [ono] właśnie tę część pokoju, w której Bungo bał się ujrzeć kogoś stojącego za nim. Tam patrzeć nie chciał, a jednak coś mu bezwzględnie nakazywało wlepiać wzrok prosto w lustrzaną głębię i najwyraźniej dostrzegał czającą się ku niemu niewyraźną postaćio ${ }^{10}$.

Ta „czająca się ku niemu niewyraźna postać” to zwierciadlane odbicie Bunga, któremu bohater nadaje w swojej wyobraźni rysy demoniczne. W ten sposób jego sobowtór, dotychczas w powieści jedynie wspominany, znajduje tu swoje lustrzane ucieleśnienie. Jego pojawienie się potęguje grozę sytuacji i sprawia, że zapatrzony w lustro Bungo czuje, iż:

jeżeli nie wstanie, to zacznie się dziać coś tak okropnego, że nie będzie w stanie znieść już przerażenia, które potęgowało się w nim z każdą chwilą. Zdawało mu się, że przestrzeń cała i jego wnętrze wypełnione są jakaśs zlodowaciałą materią i ciało swoje czuł tylko jako cienką przegrodę oddzielającą dwie nicości. Zamknął oczy i czekał ${ }^{11}$.

To doświadczenie siebie w konfrontacji z czającym się w głębi lustra „żywym” sobowtórem prowadzi bohatera powieści na skraj psychozy. Jest to doświadczenie tak porażające, że nagle zaczyna on odczuwać swoje ciało jako zlodowaciałe, jakby martwe, zawieszone między dwiema nicościami, co także bardzo przypomina opisy doświadczenia własnej cielesności przez psychotyków. Nasuwa się też skojarzenie z nicościami/przepaściami Pascala. Na szczęście Bungo zamyka oczy i po chwili

\footnotetext{
Witki ewicz, 622 upadki Bunga, s. 128.

Ibidem, s. 129.

Ibidem.
} 
słyszy wchodzącego na ganek domku Maga Childeryka, który zresztą również przypomina bardziej postać $z$ koszmaru sennego niż z rzeczywistości ${ }^{12}$.

Porażająca moc spojrzenia pierwszego sobowtóra bierze się stąd, że konfrontuje ono podmiot/Witkacego bezpośrednio ze sobą. Każe mu postawić pytanie o siebie, o to, kim właściwie jest. Czy jest tym, kogo chciał w nim widzieć ojciec? „Stanisławem Ignacym Witkiewiczem”, przyszłym „Wielkim Artysta”, który zrealizuje w swoim życiu i twórczości niespełnione ambicje ojca? Z pewnością nie. Wszak przeciw temu obrazowi, narzuconemu mu przez ojca, który sprowadza go do bycia jego kopią/sobowtórem, zbuntował się już dawno. Czy w takim razie w tym, co podmiot/Witkacy dojrzał w lustrze, znaleźć można jakąś alternatywę dla tamtej projekcji?

\section{Roz-po-czwórzony Witkacy}

Poważne, podejrzliwe spojrzenie pierwszego sobowtóra to, jak stwierdziłem, spojrzenie konfrontujace podmiot/Witkacego $z$ nim samym. I ze wszystkim, co zapisało się w jego pamięci. To jedno z niewielu zdjęć Witkacego, na którym nie przybrał on prześmiewczej miny czy pozy. Nie nałożył na twarz maski, która uchroniłaby go przed wścibskim spojrzeniem innych. Przeciwnie. Roz-po-czwórzony w dwóch lustrach, obnaża się bezwstydnie przed nimi. Wyjawia najgłębszy sekret swojej tożsamości: jej rozszczepienie na kilka sobowtórowych wcieleń. Dlatego spojrzenie pierwszego sobowtóra, patrzącego na Witkacego wprost, jest dla niego tak trudne do wytrzymania ${ }^{13}$.

W tej sytuacji wystarczy zwrócić wzrok w kierunku drugiego sobowtóra, który siedzi naprzeciw Witkacego/podmiotu przesunięty trochę na lewo. Ten drugi sobowtór już nie patrzy w jego stronę, konfrontując go bezpośrednio $z$ nim samym, ale w stronę sobowtóra trzeciego, usytuowanego naprzeciwko niego w pierwszym lustrze. $\mathrm{W}$ tej pozycji sobowtór drugi jest sprowadzony do roli bycia obiektem spojrzenia podmiotu/Witkacego. Dlatego ten może posłużyć się nim jako maską czy innym wcieleniem siebie. Może zidentyfikować się z nim tak, jak aktor identyfikuje się z rolą osoby, którą ma grać.

Ten sposób odniesienia się Witkacego/podmiotu do drugiego sobowtóra stanowi dokładne przeciwieństwo jego relacji z pierwszym sobowtórem. Tam Witkacy występował wprawdzie również w roli podmiotu spojrzenia, ale ten, na kogo patrzył (sobowtór pierwszy), odwzajemniając jego wzrok, nie dawał się sprowadzić do roli

Warto przy okazji zauważyć, że Mag Childeryk każe Bungowi opuścić Angelikę, twierdząc, iż jego związek z tą kobietą będzie niszczacy dla niego jako artysty. Jeśli opis tego związku porównamy z treścią listów Witkacego do Czerwijowskiej, która jest w powieści pierwowzorem Angeliki, uzyskujemy wgląd w całą złożoność i ambiwalentną postać intymnej relacji łączącej go z tą dziewczyna. Zob. Wit ki ew i c z, 622 upadki Bunga, s. 121-132.

13 Wprawdzie $\mathrm{z}$ taką bezpośrednią konfrontacją spojrzeń będziemy mieli do czynienia również w sekwencji drugiej (relacja sobowtóra pierwszego do drugiego), ale tam Witkacy/podmiot obserwuje ja z boku, jako grę, która toczy się na płaszczyźnie luster, jego samego jako podmiotu ona nie dotyczy. Tu zaś bezpośrednia konfrontacja spojrzeń ma miejsce między znajdującym się po „tej stronie" lustra Witkacym/podmiotem a jego fikcyjnym obrazem pojawiającym się na płaszczyźnie lustra (idealne wyobrażeniowe ,ja"). 
obiektu. Tutaj zaś drugi sobowtór jest wyłącznie obiektem jego spojrzenia. Otwiera się druga sekwencja spojrzeń, której odpowiada przyjmowanie przez Witkacego w życiu różnych min i póz. Jak pisze jego przyjaciel, Jan Leszczyński:

Obdarzony wybitnym poczuciem humoru, tym humorem maskował w dużej mierze swoją osobowość. Toteż kto nie znał go [tj. Witkacego] bliżej, dostrzegał przeważnie tylko maskę. Ta maska pokrywała dystans, który go dzielił od otoczenia; stwarzała sztuczną bliskość, której właściwie nigdy nie było i być nie mogło ${ }^{14}$.

W latach zakopiańskiej młodości Witkacego, kiedy buntował się on przeciwko „idealnemu” obrazowi siebie narzuconemu mu przez ojca, maski, które nakładał, wiązały się $z$ przyjmowaniem przez niego popularnej w modernizmie pozy dekadenta. Widać to wyraźnie w listach do Czerwijowskiej, jak też we wspomnianej, powstałej w tym okresie, powieści. Niektórych ta postawa pisarza irytowała, upatrywali w niej kabotyństwo, przyjmowanie na siłę pretensjonalnych póz. Nie dostrzegali, że te „sztuczne” zachowania były symptomem głębokich zaburzeń tożsamościowych Witkacego, związanych z jego ambiwalentnym stosunkiem do ojca, w szczególności $z$ buntem przeciw podniosłej hipokryzji i zawłaszczającym wobec niego zapędom tamtego. W późniejszych latach, czyli po powrocie w 1918 roku do Polski, Witkacy zaczął nakładać już nieco inne maski. Były to maski prześmiewcy, komika i parodysty. Tę zmianę widać również na późniejszych fotografiach (cykle komicznych min i póz) oraz w jego twórczości pisarskiej, głównie w dramatach i po części w powieściach.

\section{W węzłowisku sobowtórowych spojrzeń}

Buntując się przeciwko narzuconej mu przez ojca roli przyszłego „Wielkiego Artysty” poprzez ucieczkę w prześmiewcze pozy i maski, Witkacy ucieka przed sobą samym. Ponieważ jest jeszcze „embrionem”, nieopierzonym i nieprzygotowanym do życia młokosem, nie udaje mu się wytworzyć dostatecznie przekonującego obrazu siebie, który mógłby przeciwstawić ojcowskiemu, i z nim się zidentyfikować. Dlatego pod różnymi maskami, które przybiera w towarzystwie innych, zieje tylko nicość i pustka. I straszliwa samotność. Nawet jeśli owe maski mają pewien efekt „terapeutyczny", neutralizując doświadczenie grozy istnienia, jest to efekt chwilowy. $Z$ tego powodu każdą przybraną maskę musi zaraz zastąić inna, także przejściowa, itd. Sobowtóry masek mnożą się zatem w nieskończoność.

Jeśli więc, jak o Witkacym pisze Leszczyński, maska ironii i autoironii „była równocześnie dla niego czymś na wskroś naturalnym: była wyrazem ogólnego krytycyzmu, który nie mógł ominąc jego własnej osoby" ${ }^{15}$, to nie chroniła ona przed doświadczeniem bezsensu wszystkiego i egzystencjalnej pustki:

Gdy maska ta czasami opadała, ukazywał się na chwilę człowiek straszliwie samotny, ponury, rozbity wewnętrznie, wstrząsany potężnymi pasjami, miotany wichrem nie znanych przeciętnemu człowiekowi uczuć metafizycznych, człowiek wspaniały, twórczy i na wskroś tragiczny ${ }^{16}$. 
$\mathrm{Na}$ fotografii ten moment opadnięcia maski oddaje relacja, w jakiej sobowtór drugi pozostaje wobec siedzącego naprzeciw niego w drugim lustrze sobowtóra trzeciego, patrzącego wprost na niego. Strukturalnie stanowi ona kopię sytuacji wyjściowej (pierwsza sekwencja), czyli relacji między Witkacym/podmiotem a jego pierwszym sobowtórem. Tyle że tam Witkacy/podmiot znajdował się po „tej” stronie lustra, obecnie natomiast wymiana spojrzeń zachodzi między jego dwoma lustrzanymi odbiciami/sobowtórami, które w równej mierze mają status wyobrażeniowej fikcji.

Sytuacja wyjściowa, na którą składa się relacja „realnego” Witkacego/podmiotu do sobowtóra pierwszego, uległa tutaj zatem podwojeniu, czyli dokładnemu skopiowaniu na płaszczyźnie dwóch luster. I z pewnością relacja ta podwaja się w nich dalej bez ustanku, czego na fotografii już nie widzimy. Nie sposób przy okazji nie zauważyć, że sytuacja ta przypomina przytoczoną wcześniej scenę otwierająca pierwszą powieść Witkcego, w której świat barona Brummela przyrównuje się do „olbrzymiego labiryntu zwierciadlanych komnat”, w których odbicia wyjściowej rzeczywistości, a wraz z nimi obserwujące je „ja”, mnożą się w nieskończoność.

Powtórzenie na załamanej płaszczyźnie luster wyjściowej relacji podmiotu/ Witkacego do pierwszego sobowtóra jest jednak znamienne również pod innym względem. Podmiot/Witkacy bowiem, uciekając przed spojrzeniem pierwszego sobowtóra w lustrzaną maskę drugiego sobowtóra, napotyka w tej masce ponownie tamto „własne” podejrzliwe spojrzenie. Tyle że tym razem jest ono skierowane na niego ze strony własnego trzeciego sobowtóra, ukazującego się w drugim lustrze, który - jeśli chodzi o jego pozycję wobec sobowtóra drugiego - jest podwojona lustrzaną kopią sobowtóra pierwszego. Trzeci sobowtór kieruje bowiem na sobowtóra drugiego identyczne spojrzenie „wprost”, które sobowtór pierwszy kierował na podmiot/Witkacego w pierwszej sekwencji.

Jeśli więc między sobowtórami drugim i trzecim ma miejsce rywalizacja czy konflikt spojrzeń, to - inaczej niż w poprzednim wypadku - rozgrywa się on wyłącznie na tafli luster. To walka masek prowadzona przez dwa lustrzane sobowtóry podmiotu/Witkacego, wyobcowane w równej mierze w stosunku do niego. Przypomina ona walkę sobowtórów/cieni w chińskim teatrze. Zarazem jednak, skoro wszystkie sobowtóry Witkacego ukazujące się na płaszczyźnie luster to jego różne tożsamościowe formy, z którymi się identyfikuje, odczuwa on konflikt ich przecinających się spojrzeń jako własny. Mamy tu do czynienia z prawdziwym „węzłowiskiem” spojrzeń, nie do rozplątania.

Ponieważ w tego rodzaju konflikcie, który jest walką lustrzanych masek, nie ma ostatecznego rozstrzygnięcia, nie rozgrywa się on w myśl zasady narcyzmu: „Albo ja, albo on” (J. Lacan), ale w myśl zasady dysacjonizmu: „I ja, i on”. W tym ostatnim wypadku łącznik „i” nie implikuje harmonijnego współistnienia obok siebie dwóch wyobrażeniowych „ja”, lecz odsyła do poczucia rozszczepienia na dwa lub więcej istniejących obok siebie w permanentnym konflikcie „ja”-sobowtórów. Konfliktu tego nie określa logika walki na śmierć i życie, w której celem jest wykluczenie rywala, ale logika dysocjacji: bolesne doświadczanie permanentnego oscylowania między różnymi sobowtórowymi wcieleniami własnego „ja”, które istnieja na równych prawach w swej samoistności.

Mimo tego, że podmiot/Witkacy nieustannie przemieszcza się między wcieleniami, zmieniając swą pozycję wobec siebie i innych, nie może on ustalić, które 
z nich jest naprawdę jego. Dlatego zmianę pozycji, założenie nowej maski na siebie odczuwa za każdym razem jako coś bardzo bolesnego, „o natężeniach dochodzących do siły normalnego bólu brzucha" ${ }^{17}$. Nigdy nie jest ona bowiem ostateczna, nie prowadzi do eliminacji „tego drugiego”. Ten wszak, nawet gdy zanegowało się jego istnienie, zawsze powróci, starając się zająć miejsce podmiotu. Na tym polega dramat uwikłanego w ów konflikt podmiotu, który Witkacy, nawiązując do typologii Ernsta Kretschmera, nazywa schizoidem:

Ważnym jeszcze dla psychiki schizoida jest to, że są to typy zasadniczo rozdwojone [...] - bo o podwójnej w ścisłym znaczeniu osobie psychicznej nie ma tam mowy: przeciwieństwa mieszczą się w jednej osobie jednocześnie - to jest najciekawsze. [...] Doprowadzony stan ten do ostatnich konsekwencji daje dwie psychiki w obrębie jednej osobowości, nie wiedzące jakby nic wzajemnie o sobie ${ }^{18}$.

Schizoid to, innymi słowy, podmiot rozszczepiony, który nie jest w stanie panować nad swoimi „sobowtórami”. Dlatego nierzadko zachowuje się w sposób niespójny, tak jakby istniało w nim kilka osób naraz. W ten sposób postępuja często bohaterowie dramatów i powieści Witkacego, ukazując nieoczekiwanie w trakcie rozwoju akcji swoje zupełnie nowe oblicza, które nie korespondują $z$ dotychczasowymi. Takim bohaterem jest np. Bałandaszek w Onych, najpierw zrywający ze swoją kochanką Spiką, aby związać się z „czarną” kobietą, żoną hrabiego Tremendoza, pożądaną przez siebie - czego sam nie rozumie - do nieprzytomności, a następnie, po śmierci Spiki, zrywa $z$ tamtą, poniewczasie wyznając swej martwej kochance miłość. W podobnie nieoczekiwany sposób Tumor Mózgowicz w miarę jak rozwija się akcja dramatu, zmienia swój stosunek do dzieci i żony, zrywając stopniowo, po kolei, wszelkie więzy z nimi. Zmienia się też często postawa kobiet wobec mężczyzn, z którymi są związane; najpierw zapewniają ich o swojej miłości, później okazują im niezmierzona pogardę, niekiedy próbuja uśmiercić, aby następnie znowu wrócić do postawy miłosnego uwielbienia (np. Iza z Tumora Mózgowicza, Ellinor z Mister Price, Serafombyx z Niepodległości trójkątów). Równie rozdwojoną strukturę osobowościową mają Walpurg z Wariata i zakonnicy, Tadzio z Kurki Wodnej, Karmazyniello z Metafizyki dwugłowego cielęcia czy główni bohaterowie powieściowi, jak Atanazy w Pożegnaniu jesieni, rozdarty między narzeczoną Zosią a kochanką Helą Bertz, czy Zypcio z Nienasycenia.

Podobne konstruowanie przez Witkacego tożsamości protagonistów dramatów i powieści jako rozszczepionych na kilka osobowości i targanych sprzecznymi pragnieniami „schizoidów” jest zgodne z podstawową zasadą jego „psychologii fantastycznej”, która ma określać wyłamujące się z norm życia codziennego zachowania tych postaci. Dlatego ukazane w Autoportrecie „węzłowisko” spojrzeń między pojawiającymi się tu sobowtórami może posłużyć za dogodny punkt wyjścia w rozpoznawaniu powikłanych związków między bohaterami dramatów i powieści Witkacego, niemal każdy z nich jest jakimś sobowtórem pisarza i kobiet, które spotkał on w życiu. Jak trafnie o zjawisku „roz-po-czwórzenia” tożsamości Witkacego mówi Ewa Łubieniewska:

18 S. I. Witki ewi cz, Narkotyki. - Niemyte dusze. Wstęp, oprac. A. Mi cińs ka. Warszawa 1975, s. 203. 
utrwalone na fotografii w całej przejmującej dosłowności, w dramatach przyjmuje [ono] kształt dyktowany przez konwencję teatralną: poszczególne figury sceniczne (choć przywdziewają maski różnych postaci) wydają się być częścią je d n ej rozszczepionej psychiki, która - poprzez tego rodzaju projekcję - fałszywie „obiektywizuje” przeżywane dylematy wewnętrzne. [...] Rozpoznając kondycję człowieka jako kondycję aktora (i m i t a t o r a osoby), [Witkacy] odsłania tym samym widmowy sposób egzystencji owej efemerydy, a zarazem uzmysławia tego konsekwencje: dezintegrację, rozpad, zanik podmiotu, miotanego sprzecznymi rozkazami wewnętrznych popędów ${ }^{19}$.

Same te widmowate postaci przy tym często podwajają się w kolejnych lustrach wyobraźni pisarza, stając się sobowtórami samych siebie. Można powiedzieć, że postaci te się sobo-wtórzą. Ma to miejsce w dramatach, gdzie bohaterowie często ożywają po swojej śmierci, która - jak się okazuje - była tylko chwilowa i pozorna, oraz wracają na scenę w nowych wcieleniach. A dzieje się tak dlatego, że od samego poczattku przysługiwał im status nieśmiertelnych lustrzanych widm. Ostatecznie wszystko rozgrywa się tu - jak w Autoportrecie - w fikcyjnym lustrzanym świecie niby-snu, który nie zna pojęcia śmierci.

\section{Czwarty sobowtór - analityk i obserwator}

Pozostał nam jeszcze sobowtór czwarty. Usytuowany jest on po lewej stronie podmiotu/Witkacego i patrzy z boku na sobowtóra trzeciego. Sobowtór ten zamyka drugą sekwencję spojrzeń, będąc jako taki niewidoczny dla podmiotu/Witkacego. $Z$ tej racji nie jest uwikłany w grę spojrzeń toczącą się zarówno między podmiotem/ Witkacym a jego sobowtórem pierwszym, jak i między sobowtórami drugim i trzecim. Kieruje wzrok na sobowtóra trzeciego, przez którego jednak nie jest zauważony, jego istnienia nie postrzegają też pozostałe sobowtóry ani sam podmiot/Witkacy. $Z$ jednej strony, wydaje się przez nich całkiem zignorowany, $z$ drugiej strony - właśnie dlatego może spokojnie śledzić toczącą się między nimi grę spojrzeń. Ten sobowtór to jakby wcielenie obserwującego ,ja” pisarza, o którym jest mowa w 622 upadkach Bunga. To ,ja”-obserwator pojawia się w świecie barona Brummela i Bunga, mnożąc się w nieskończoność w odbiciach luster, które składają się na ów świat. Równie dobrze można w takim obserwatorze widzieć ,ja” analizujące nieustannie siebie i innych. To sobowtór-analityk, który wziął na poważnie i realizuje w swojej twórczości wezwanie zakopiańskiego psychiatry Karola de Beauraina do ciagłego analizowania się przez podmiot. Tak jak mówi o tym piosenka Witkacego:

\footnotetext{
Analyse yourself at once, I say -

If not immediately, but by the way.

And if you don't, and if you don't,

You are a lazy mastodont ${ }^{20}$
}

20 Cyt. za: J. Wi tki ew i c zow a, Wspomnienia o Stanisławie Ignacym Witkiewiczu. W: S. I. Witk i e w i c z, Listy do żony. Cz. 4: 1936-1939. Przygot. do druku A. Mi c ińs ka. Oprac. J. D e gle r. Warszawa 2012, s. 494. Dzieła zebrane. T. 22.

Przekładu tego wierszyka dokonał J. Gondowicz (w: Witkiewicz, Listy do żony. Cz. 2: 1928-1931. Przygot. do druku A. Mi cińs ka. Oprac. J. D e gler. Wyd. 2, popr. i uaktualnione. Warszawa 2015, s. 494. Dzieła zebrane. T. 20), wprawdzie dowcipnie, ale w sposób dość odległy znaczeniowo od oryginału: 
Na znaczącą rolę tego typu „analizującego” siebie sobowtóra w pisarstwie Witkacego wskazuje Jan Błoński w swojej książce, nazywając go „obserwatorem”:

Obserwator to „tajemny głos” [...], „spojrzenie z boku” [...], nadświadomość; on czyni z Atanazego „nałogowego analityka” [...]. Właśnie obserwator niszczy bezpośrednie przeżywanie i zmusza do coraz wymyślniejszych perwersji uczuciowych ${ }^{21}$.

Ponieważ tego typu sobowtór mnoży się w nieskończoność w odbiciach lustrzanych, wynik jego „analiz” nigdy nie jest ostateczny. „Analiza” zawsze musi zostać powtórzona $\mathrm{w}$ kolejnym odbiciu-lustrze. Postać tego widmowatego obserwatora-analityka otwiera pierwszą powieść Witkacego, o czym już pisałem. Jest to postać tragiczna. Nawet jeśli autor ustawia przed bohaterem lustro analizy i krytycznej refleksji, nie udaje mu się wyzwolić go od „węzłowisk”, w które ten się zaplątał. Przeciwnie. Wikła go w nie jeszcze bardziej, „wzbogacając” je o wymyślne eksperymenty uczuć i chuci. Dlatego trudno nie zgodzić się z końcową konkluzją Błońskiego, który nawiązując do postaci głównych bohaterów Jedynego wyjścia, artysty Marcelego i filozofa Izydora, stwierdza, że Witkacy rozdzielił między nich funkcje psychiczne „sobowtóra” i „obserwatora”:

Wszędzie jednak powraca przekonanie, że człowiek jest wielokształtny i nie umie ustalić równowagi między sobowtórami, w które się wciela i z których ucieka. Wszędzie też intelekt (wyodrębniony w „obserwatora”, o którym mowa już w 622 upadkach Bunga) unosi się, złośliwy i bezpłodny, nad spienionym bezmiarem nieposkromionych ambiwalencji uczuciowych ${ }^{22}$.

Czwarty sobowtór/obserwator nie jest w stanie nic zmienić w konfliktowej wzajemnej relacji sobowtórów drugiego i trzeciego. Jeśli nawet coś wynika z jego „analiz” tego, co widzi u siebie i innych, jest to zazwyczaj albo trudne do zaakceptowania przez podmiot, albo niemożliwe dlań do zrealizowania. Nieprzypadkowo Bałandaszek w Onych ostrzega sam siebie „Niech bóstwa wiecznej ciemności mają was w swej opiece. Strzeż się analizy uczuć istotnych, panie Kalikście”23. Później zaś, targany sprzecznymi pragnieniami - z jednej strony wyrzutami sumienia wobec narzeczonej, która porzucił, $z$ drugiej niezrozumiałym, silniejszym od niego pożądaniem czarnej kobiety - ma poczucie, że mózg mu „się rozłazi jak rozpalona magma”. I mówi do Tefuana: „Ale uratował mnie pan od analizy. Czasem dobra cytata $z$ jakiegoś morowego pana $z$ przeszłości więcej znaczy niż tysiące doświadczeń

Zanalizuj się pan daję słowo,

Kompleksowo, a bodajże zdawkowo,

Bo kto ma w nosie wzgląd na wgląd,

To gnuśny $z$ niego mastodont.

Ponieważ nie ma czegoś takiego jak „zdawkowa” autoanaliza, załączam mój przekład, trochę toporny, ale bliższy oryginałowi:

Zanalizuj siebie w końcu, powiadam ci,

jeśli nie zaraz, to przy okazji.

A jeśli nie, jeśli nie zrobisz tego,

to jesteś leniwym mastodontem, kolego.

J. Błoński, Witkacy na zawsze. Kraków 2003, s. 436. Przytoczone przez Błońskiego cytaty pochodzą z Pożegnania jesieni Witki ew i c za $(\mathrm{s.} 12,20)$.

22 Ibidem.

23 S. I. Witkiewicz, Dramaty. T. 1. Oprac. J. Degler, A. Micińska. Wyd. 2, uaktualnione. Warszawa 2016, s. 390. Dzieła zebrane. T. 5. 
obecnych" 24 . Dodajmy, że chodzi w tym wypadku o wypowiedź zdrajcy Cade'a z Króla Henryka VISzekspira „Myśmy tylko wtedy w największym porządku, gdyśmy w największym nieporzadku"25.

„Nieporządek” tym samym, stan rozchwiania emocjonalnego, dysocjacji jest naturalnym stanem psychicznym, który analiza może jedynie pogorszyć, próbując wprowadzić w jego miejsce jakiś sztuczny „porządek”. W ten sposób Witkacy nie tylko opatruje znakiem zapytania przekonanie de Beauraina, że dogłębna analiza siebie jest w stanie uwolnić podmiot od prześladujących go kompleksów. W równej mierze wyraża swoją wątpliwość wobec przesłania zawartego w przytoczonej tu, wymyślonej przez siebie piosence o analizie. Analiza siebie niewiele pomoże, kiedy jej obiektem stają się kluczowe „węzłowiska” duszy podmiotu, niemożliwe do rozwiązania ze swej istoty. Lepiej jest zdać się wówczas na „bóstwa wiecznej ciemności”, na mroczne siły nieświadomego.

Inna sprawa, że mimo tych buńczucznych wypowiedzi bohaterowie dramatów i powieści Witkacego często analizują siebie, stawiają pytania o własną tożsamość i o źródła „nieporządku”, który określa ich dusze. Pierwiastek ,analityczny" przejawiający się w dokonywanej przez nich refleksji nad sobą jest nieustannie widoczny $w$ ich odnoszeniu sie do siebie. Jakkolwiek psychoanaliza, zdaniem Witkacego, nie jest w stanie wyzwolić podmiotu od jego „węzłowisk”, to uświadamiając mu ich naturę, pozwala wypracowywać strategię umiejętnego obchodzenia się z nimi i ich neutralizowania. Witkacy nie odmawia psychoanalizie walorów emancypacyjnych, czyli wpływania na postać samowiedzy podmiotu i na jego poczucie tożsamości.

Wymowny wyraz temu poglądowi da pod koniec lat trzydziestych w obszernej rozprawie Niemyte dusze, opublikowanej jednak dopiero $30 \mathrm{z}$ górą lat po jego śmierci. Pisarz kreśli w niej projekt przeobrażenia przez psychoanalizę typu freudowskiego dominującego - jego zdaniem - wzorca tożsamościowego Polaków, polegającego na „puszeniu się” z racji ich faktycznego lub uzurpowanego sobie „wyższego” szlacheckiego pochodzenia. W ten sposób dzięki psychoanalizie mają się oni uwolnić od własnego kompleksu niższości ${ }^{26}$.

\section{Sobowtórzenie Witkacego i tożsamościowy dysocjacjonizm}

Jak już wspomniałem, Autoportret Witkacego można odczytać jako metafore jego dysocjacyjnej struktury tożsamościowej. Stefan Okołowicz we wstępie do albumu zdjęć pisarza zauważa, że w przypadku tej fotografii nie chodzi tylko o rodzaj wyrafinowanej gry Witkacego $z$ własnymi lustrzanymi odbiciami, ale również o bezpośrednią konfrontację $z$ samym sobą, która jest traktowana przez niego najzupełniej serio. Na fotografii tej rozgrywa się, rzutowany na płaszczyznę dwóch luster, dramat,

Ibidem, s. 417.

Ibidem.

Witkacy/podmiot siedząc w pozycji ukazanej na fotografii, może dostrzec tylko sobowtóra pierwszego i sobowtóra drugiego, które znajdują się naprzeciw niego pod kątem 135 stopni. Natomiast sobowtóry trzeci i czwarty usytuowane są wobec niego pod takim katem, że Witkacy ich nie widzi. Aby je zauważyć, musiałby zwrócić w ich kierunku głowę, czyli zmienić pozycję, jaką przyjął na fotografii. 
który zaczął się w latach młodości i później towarzyszy pisarzowi przez całe życie. To dramat rozszczepienia własnej tożsamości na kilka odbić/sobowtórów, $z$ których każdy jest i nie jest nim samym. Te zaś znowu się podwajają, powołując do istnienia swe kolejne sobowtóry. Sobowtóry sobowtórów. To dramat sobo-wtórzenia siebie i wikłania się w rozgałęziające się coraz bardziej sobo-wtórowe węzłowiska.

Dramat ten w życiu i twórczości Witkacego znajduje wyraz w stawianiu pytań egzystencjalnych o charakterze „granicznym”, w których dochodzi do głosu jego niepewność co do tego, kim się jest i po co. Witkacy zadaje je nieustannie w listach, esejach, ustami bohaterów w swoich dramatach i powieściach: „kim właściwie jestem?”, „po co się urodziłem i za czyją sprawą?”, ,jaką rolę w mym pojawieniu się odegrali ojciec i matka?”, „czy moje istnienie i istnienie świata ma w ogóle jakiś sens?" Uporczywe stawianie przez niego tych pytań świadczy o tym, że od lat młodości miał on problem $z$ akceptacją siebie w roli „Stanisława Ignacego Witkiewicza”, idealnej kopii swego ojca.

Jeśli jednak z czasem pisarz zaczął kwestionować takie potraktowanie siebie przez ojca, to nie był w stanie przeciwstawić jego projekcjom wykreowanej przez siebie stabilnej tożsamościowej formy, z którą mógłby się bezproblemowo zidentyfikować. W rezultacie wzorzec ojcowski stał się w jego oczach prześladujacym go własnym sobowtórem, niechcianym podwojeniem siebie, towarzyszącym mu w życiu niczym cień. Wiele świadectw z tamtego okresu, przede wszystkim listy do Czerwijowskiej, świadczy wymownie o tym, że jako główną strategię obronną wobec instrumentalnego potraktowania przez ojca Witkacy obrał ucieczkę w różne, już to wymyślone przez siebie, już to zaoferowane mu przez epokę role i pozy.

Ta strategia nie zmieni się po wydarzeniach, jakie miały miejsce w życiu pisarza między 1914 a 1918 rokiem: po samobójczej śmierci Janczewskiej, podróży z Malinowskim w tropiki, pobycie w Petersburgu w elitarnym pułku carskim, uczestniczeniu w działaniach wojennych, później zaś w rewolucji rosyjskiej w roku 1917. Witkacy będzie multyplikował siebie na płaszczyznach kolejnych luster, ruszy w pościg za swoimi kolejnymi sobowtórami.

Po powrocie do kraju w 1918 roku nastąpi u niego prawdziwa eksplozja mocy twórczych, która będzie trwała aż po lata trzydzieste. Witkacy pisze kilkanaście sztuk, trzy powieści oraz dziesiątki artykułów i polemik różnego rodzaju. I kontynuuje działalność malarską. Zaraz po powrocie do kraju przystępuje do formistów i organizuje z nimi szereg wystaw, na których prezentuje swoje prace malarskie. Wykonuje też całe cykle fotografii, na których prezentuje różne wersje prześmiewczych min i póz, parodiując wybrane osoby, a często przy tym i siebie.

W latach trzydziestych zamienia lustro literatury na lustro filozofii, nazywane wzniośle „monadyzmem biologicznym”, chociaż biologii w nim niewiele. Prędzej zwrócona podskórnie przeciwko demolującej Witkacego psychicznie postawie ojca, dramatyczna próba wykazania niepowtarzalnej wyjątkowości każdej ludzkiej egzystencji pod nazwą „Istnienia Poszczególnego”, o trwałym, jednolitym ,ja”. W owym „ja” (idealnym) można dopatrzyć się osobliwego Nad-Sobowtóra, który wiążąc w sobie wszystkie dotychczasowe wcielenia jednostki, nadaje niepowtarzalny indywidualny wymiar jej istnieniu.

Ale ten Nad-Sobowtór jest również pojęciową konstrukcją o fikcyjnym statusie, której w życiu i twórczości pisarza tak naprawdę nic nie odpowiada. Wystarczy 
spojrzeć na wspomniane cykle fotografii, gdzie Witkacy występuje zazwyczaj w roli parodysty i prześmiewcy, poczytać jego listy i świadectwa osób, które go dobrze znały. Wyłania się z nich obraz człowieka targanego sprzecznymi uczuciami, rozszczepionego na wiele osobowych wcieleń, między którymi nie potrafi on ustanowić równowagi i harmonii. Podobnie rozdarta i popękana jest też struktura tożsamościowa głównych bohaterów jego dramatów i powieści, którzy nie mogąc wytrzymać horroru dziejących się wokół nich zdarzeń, kończą albo aktem zbrodni, albo samobójstwem.

Zarysowany tu dramat tożsamościowy Witkacego rozgrywa się między nim jako „realnym” podmiotem a jego zwierciadlanymi sobowtórami, $z$ którymi jego identyfikacja ma zawsze charakter chwilowy. Dlatego nakładając na siebie ich maski, już zawsze gra nimi, parodiuje i przedrzeźnia. Rozkoszuje się nimi, ale zarazem czuje się w nich wyobcowany wobec siebie. Jest przecież w istocie kimś innym niż poza, którą przybrał. Tyle że w owym domniemanym „prawdziwym” obrazie siebie skrytym pod maską pozy nie ma nic. Zieje tam tylko przeraźliwa samotność i pustka.

W dodatku same te maski często pozostają ze sobą w konflikcie. Z jednej strony, rozpoznajac się w lustrze projekcji ojca i jego „toksycznych” pochwał, Witkacy podświadomie czuje, że jest nieprzeciętnie utalentowanym artystą i pisarzem. Tyle że mającym całkiem inne wyobrażenia na temat sztuki niż te, które chciałby mu narzucić ojciec. Stąd przyjmowana przez Witkacego poza puszącego się „pawia”, co Bungowi - jego powieściowemu sobowtórowi - wytyka Tymbeusz. Z drugiej strony, pisarz, zdając sobie sprawę, że jego poglądy na sztukę i na to, co tworzy, są dalekie od tego, czego oczekiwał od niego ojciec, ma niejasne poczucie, że zawiódł go pod tym względem. Choć naturalnie nigdy się do tego nie przyzna, tylko ciągle będzie podkreślał swoją odrębność i „wyższość” jako artysty.

Nie uchroni go to jednak przed powracającymi cyklicznie załamaniami psychicznymi i chwilami zwątpienia w wartość tego, co tworzy. Stąd powtarzane przez niego obsesyjnie w listach do Czerwijowskiej, a później do żony, twierdzenia, że nie jest żadnym artystą (albo że skończył się jako artysta). Oraz towarzyszacy tym twierdzeniom lęk przed całkowitym popadnięciem w szaleństwo. W dodatku niemal wszyscy w Zakopanem, łącznie $z$ „Kotusiami”, uważają, że Witkacy jest artystą-degeneratem, dziwkarzem, pijakiem i w ogóle nie dorasta ojcu do pięt. I często daja mu to bez ogródek do zrozumienia. Dlatego widmo ojca-moralizatora, który skradł mu jego tożsamość, będzie go prześladować do końca. Jeśli wszystko w życiu i twórczości Witkacego będzie aktem buntu przeciwko ojcu, to zarazem będzie też bezwiednym poświadczeniem własnej zależności od niego.

Ale bodaj najbardziej wymownym dowodem tych obsesji i lęków są pojawiające się w dramatach Witkacego typy bohaterów: artystycznych grafomanów i życiowych nieudaczników. Marzą oni, by stworzyć dzieła wielkie i zrobić kariere jako artyści, lecz jednocześnie mają niskie poczucie własnej wartości. Takimi postaciami są Leon Węgorzewski w Matce, Kuzyn Jęzory Pasiukowski w dramacie W małym dworku czy Kalikst Bałandaszek z Onych.

To oscylowanie między pragnieniem bycia „wielkim artysta”, który kreuje dzieła wyrastające ponad epokę, a poczuciem, że w istocie jest się tylko żałosnym grafomanem bez talentu, widać szczególnie wyraźnie w Sonacie Belzebuba. W groteskowej, bezlitośnie sparodiowanej formie, ukazany został tu - przywołany przez 
Goethego w Fauście, później zaś, ubrany w modernistyczną szatę, w słynnej powieści Thomasa Manna - mit paktu artysty z diabłem. U Witkacego nastąpiło przewrotne odwrócenie toposu, który składa się na ów mit. W roli artysty występuje tu Baleastadar, który jest samym Belzebubem, księciem ciemności, natomiast jego sobowtórem/medium - a jedynie to pośrednictwo pozwala bohaterowi stworzyć wymarzone wielkie muzyczne dzieło - jest młody muzyk Istvan.

W tej rozdwojonej diabelsko-ludzkiej homoseksualnej parze widzimy jak na dłoni cały wspomniany dramat pojmowania przez Witkacego siebie jako artysty. Baleastadar ma wprawdzie potężną energię twórczą, niezbędną do wykreowania wielkiego dzieła, ale sam takiego dzieła nie jest w stanie zrealizować. Do tego potrzebuje „medium”, innego artysty, na którego przenosząc tę energię dopiero owo dzieło skomponuje. Baleastadar zatem bez swego sobowtóra - Istvana, jako artysta jest nikim, zwykłym impotentem, którego ogromna moc twórcza nie może się urzeczywistnić. Ale impotentem jest bez Baleastadara również Istvan, który nie dysponując zaprojektowaną na niego przez tego pierwszego energia twórczą powołałby do istnienia dzieło grafomańskie, niewarte wzmianki.

Nie dość tego. Pod koniec sztuki okazuje się, że sadomasochistyczna relacja między Baleastadarem a Istvanem jest niszcząca dla tego ostatniego, który na scenie zmienia się w bezduszny, martwy automat i opuszcza ją w milczeniu. Wygląda to tak, jakby Baleastadar wyssał z niego w międzyczasie wszystkie życiowe soki. Jeśli skonfrontujemy tę scenę $z$ wypowiedziami Witkacego w listach do Czerwijowskiej, w których twierdził, że jako Stanisław i Ignaś jest trupem, i odniesiemy ją do jego relacji z ojcem, nie sposób oprzeć się wrażeniu pokrewieństwa obu tych relacji.

Na to schizofreniczne pojmowanie aktu twórczego, określanego od wewnątrz przez głęboki antagonizm, rozdwojenie na „diaboliczny” podmiot będący źródłem energii twórczej i mechanicznego wykonawcę-medium, sobowtóra, na którym ów podmiot pasożytuje, nakładają się w myśli estetycznej Witkacego innego typu „węzłowiska”. Z jednej strony, zafascynowany współczesnymi teoriami awangardowymi, w szczególności kubizmem, uważa on, że sztuka współczesna winna zerwać z wyznawana przez ojca estetyką realizmu (a właściwie naturalizmu, jak pisze) oraz odejść od urzeczywistniania zadań narodowych i społecznych. Zamiast tego artysta tworzac dzieło sztuki powinien kierować się jego formalną ideą konstrukcyjną, uwalniając je od wszelkich życiowych treści. Te poglądy rysują się już wyraźnie w 622 upadkach Bunga, później swoją rozwinięta postać znajdą w teorii Czystej Formy, której podstawowe tezy Witkacy zwraca przeciw ojcu i teoriom sztuki realistycznej.

Z drugiej strony jednak - w krzywym zwierciadle świata jego dramatów oraz obrazów, przesyconych parodią i groteską, ukazuje się mocno zniekształcone oblicze świata, w jakim pisarz żyje. Obnażana jest sztuczność czy konwencjonalność określających ten świat norm i zasad, absurdalność, bezmyślność, a także okrucieństwo popularnych w nim idei społecznych i politycznych. Ukazuje się jego druga, skrywana na co dzień, strona. Równocześnie przez dziejące się w nim zdarzenia, przez absurdalny automatyzm zachowań bohaterów przeziera mroczna wizja najbliższej przyszłości, w której jednostka stanie się bezwolnym obiektem w ręku rządzących sił politycznych. Dzięki najnowszym zdobyczom nauki i techniki będą one mogły, poprzez aplikację odpowiednich pigułek, wpływać na poglądy 
jednostki i na jej konstytucję biologiczno-fizjologiczną. Wbrew deklaracjom teoretycznym Witkacego uwidacznia się zatem w jego dramatach sama, ukazana w zwierciadle groteski i absurdu, kwintesencja „treści” świata, w jakim pisarz żyje.

Podobnie też, wbrew deklarowanemu przez Witkacego antypsychologizmowi, głoszona przez niego „fantastyczna psychologia”, która ma określać zachowania bohaterów dramatów, jest w istocie również rodzajem psychologizmu. Tyle że nie psychologizmu pojmowanego w duchu realistycznym, sprowadzającego życie psychiczne człowieka do przeżyć świadomości, ale „psychologizmu” ześrodkowanego wokół pojęcia nieświadomego („podświadomości”), w którym kluczową rolę odgrywają popędy i wyrastające na ich podłożu „fantastyczne” ludzkie pragnienia.

Najbardziej fundamentalna sprzeczność dotyczy wszakże poglądów Witkacego na sztukę. $Z$ jednej strony, opracowana przez niego teoria Czystej Formy oddawać ma kwintesencję tego, co estetyczne, i stanowić apogeum dotychczasowej myśli o sztuce. $Z$ drugiej strony - cała tradycja tej myśli, u której podstaw tkwi założenie, że dzieło sztuki jest wytworem genialnego indywiduum, ma zostać w najbliższej przyszłości zniwelowana przez pojawienie się quasi-komunistycznego porządku społeczno-politycznego. W tym porząaku nie będzie się liczyć żadne indywiduum, ale byt jednostki we wszystkich swych aspektach zostanie podporządkowany interesowi zbiorowemu. Tym samym zaś zabraknie w nim w ogóle miejsca na sztukę. Rozpatrywana w takiej perspektywie teoria Czystej Formy jest aktem agonalnym tej tradycji, ostatnim wykwitem myśli estetycznej, który już niedługo i tak odejdzie w zapomnienie.

\author{
Abstract \\ PAWE DYBEL Pedagogical University, Cracow \\ ORCID: 0000-0002-4757-9991
}

\title{
WITKACY'S LOOKALIKE CONVERTING
}

The author's basic principle in the article is an analysis of the relation borne between Witkacy and his four mirror images in the famous photography Autoportret wielokrotny w lustrach (Multiple Self-Portrait in Mirrors). Extracting the structure of the relations, the paper shows that it is conceived of as a peculiar metaphor of Witkacy's dissociative identity structure as each of the mirror lookalikes is one of his own incarnations. Witkacy's dividing-into-four seen in the photography is a starting point to the lookalike-converting taking place in the writer's private life, i.e. to constant striking poses and putting on masks. The study also shows that the writer's reference to each of the lookalikes corresponds with the many motifs and caricaturally constructed phantom-like figures in his dramas and novels. In this sense the structure of the Witkacy's relation to the four of his lookalikes in Autoportret wielokrotny $w$ lustrach (Multiple Self-Portrait in Mirrors) may be seen as an initial interpretive key in reference to the whole of his literary output. 